\title{
Population structure and reproductive biology of Mesopodopsis orientalis (Crustacea: Mysida) in a tropical mangrove ecosystem in India
}

\author{
A. Biju *, S.U. Panampunnayil \\ National Institute of Oceanography, Regional Centre, Dr. Salim Ali Road, \\ Ernakulam North P.O, Cochin-18, Kerala, India
}

\begin{abstract}
The population structure and biological aspects of the shallow water mysid Mesopodopsis orientalis were studied in the Versova mangrove, Mumbai, India. The monthly collections ranged from $0-2104$ ind. $\mathrm{m}^{-3}$ with an average of 78.6 ind. $\mathrm{m}^{-3}$. The sampled population was found in a wide range of temperature $\left(25.5^{\circ} \mathrm{C}\right.$ to $\left.34^{\circ} \mathrm{C}\right)$ and salinities $(20.3$ to 37.1$)$. Carapace length significantly correlated with total body length $(\mathrm{P}<0.01)$. Mesopodopsis orientalis breed throughout the year but there is a seasonal variation in the intensity of breeding. The size of mature males and females was at maximum during post-monsoon period. The species produced more than one generation per year and the number of embryo carried by a single female ranged from 6 - 18, and was correlated with female body length $\left(\mathrm{R}^{2}=0.69\right)$. Egg size varied between 0.32 and $0.45 \mathrm{~mm}$, with no correlation with length of females.
\end{abstract}

Key words: population, reproductive trait, Mesopodopsis orientalis, mangrove, India

*Corresponding author email address: bijuanio75@gmail.com

Telephone: +9104842390814

Fax: +914842390618

Present address. Biju.A, Research \& P.G Department of Zoology, St. Stephen's College, Pathanapuram, Kerala 689695, India.

Running head: Biology of Mesopodopsis orientalis 


\section{INTRODUCTION}

Mysids crustaceans are one of the major components of coastal and estuarine zooplankton communities and play an important role as a resource for many organisms that use these areas as nurseries. Mysids are an important link in the food web of coastal ecosystem (Yamada et al., 2007) and are prey for various fishes (Takahashi et al., 1999; Baldo \& Drake, 2002; Jumars, 2007) as well as for invertebrates, birds and seals (Mauchline, 1980) thereby linking primary and secondary production to higher trophic level. As an energy converter at different trophic levels, the significance of mysids in an ecosystem has been greatly underestimated. Mesopodopsis orientalis is one of the most important components of the shallow-water crustacean community (Hanamura et al., 2008a) and dense shoals of this species exploited for human consumption in costal areas of India and Thailand (Mauchline, 1980; Chaitiamwonges \& Yoodee, 1982; Patil \& Sankolli, 1991). M. orientalis are also food source of dolphin (Tattersall, 1915) and sea horses (Pinkaew et al., 2001). Due their high nutritive quality, this species is suitable for aquaculture as a live feed (Biju et al., 2009). Although considerable literature on the occurrence and abundance of this species from different areas exist (see Biju et al., 2009), no published information is available on its population composition and reproductive biology in mangrove habitat. Hanamura et al. (2008a) reported the reproductive biology of $M$. orientalis from a tropical mangrove estuary, but subsequent studies found that these populations belong to a different species (Mesopodopsis tenuipes). Mauchline (1980) point out that life history characteristics of mysid species can vary considerably from on habitat to another, hence knowledge on the biology of local populations is essential for subsequent studies on related scientific field (Hanamura et al., 2009). Considering the ecological and economic importance, the present study aims to elucidate the population structure, size variation within the population, breeding season and fecundity of M. orientalis in a mangrove habitat.

\section{MATERIALS AND METHODS}

\section{Description of study area}

Mangroves are salt tolerant forest ecosystem of tropical and subtropical intertidal regions. Where conditions are sheltered and suitable, the mangroves may form extensive and productive forests, which are reservoirs of a large number of species. The study site was located in the Versova mangrove $\left(19^{\circ} 7^{\prime} 30^{\prime \prime} \mathrm{N}\right.$ and $\left.72^{\circ} 49^{\prime} 30^{\prime \prime} \mathrm{E}\right)$, it is a shallow salt marsh along the tidal creek of Mumbai (Figure 1) with a depth of about 1 to $1.5 \mathrm{~m}$ and has a width ranging from 30 to $40 \mathrm{~m}$. During flood tide, flow of seawater towards the upstream progressively inundates the creek and during extensive 
high tides, even the swamp vegetation is submerged. The dominant vegetation of swamp is the mangrove species Avicennia alba which has a height of $1 \mathrm{~m}$ (Stephen et al., 2003). Vijay et al. (2005) reported that mangrove habitat around Mumbai is disappearing due to human interference.

\section{Sampling procedure and data analysis}

A total of four stations (V1-V4) were selected in the Versova mangrove, Mumbai, India for the present study (Figure 1). Station 1 (V1) is situated at the mouth of the shallow tidal creek with sandy substratum and the other three stations are located towards the northern end of the creek and are at equidistance. Monthly sampling was done regularly at all stations for 15 months from May 1991 to July 1992. Water samples from surface waters were collected using a polyethylene bucket for the estimation of temperature and salinity.

A circular hand net of $1 \mathrm{~m}$ length, having a mouth area of $0.08 \mathrm{~m}^{2}$ and a mesh size of $0.1 \mathrm{~mm}$, fitted with a calibrated TSK (The Tsurumi-Seiki Co, LTD) flow meter was used for the collection of zooplankton samples. Samples were preserved in 5\% buffered formalin. In the laboratory, mysids were sorted and classified into different groups based on the degree of development of secondary sexual characteristics. Sexes can be distinguished by observing an extended fourth pleopod in male and the growing marsupium in females. Immature individuals were distinguished from juveniles by the presence of rudimentary oostegites (female) and a longer fourth pleopod (male). The total body length of each individual was measured, from the tip of the rostrum to the posterior end of the telson, excluding the setae. Carapace length (CL) was measured from the tip of the rostrum to the posterior lateral margin of the carapace with an accuracy of $0.01 \mathrm{~mm}$. After sexed, they were categorized into six population categories based on following criteria: juveniles (J- secondary sexual characteristics are absent), immature males (IM-secondary sexual characteristics developing), mature males (MMsecondary sexual characteristics completely developed), immature females (IF- rudimentary marsupium present), brooding females (BF- carrying egg/embryo), and empty females (EFsecondary sexual characters fully developed, but no eggs or larvae are carried). Each breeding females were also classified in three categories corresponding with the stages of eggs/embryos carrying in their brood pouch, i.e. females with spherical egg like embryo (stage I) (as "egg" in this paper), females with eyeless embryos (stage II) and females with eyed embryos (stage III).

The developmental stages of eggs/embryo were classified according to Hanamura et al. (2008a): spherical egg like embryo $\left(D_{1}\right)$; eyeless embryo $\left(D_{2}\right)$; and eyed embryos $\left(D_{3}\right)$. The egg diameter was measured along the longest axis. Stage $\mathrm{D}_{2}$ and $\mathrm{D}_{3}$ embryos were measured along the 
distance between the anterior end (ventral side) and the posterior end of the uropod without stretching the body.

Monthly histograms with total length of each population category were used to analyse the population structure of $M$. orientalis using $1 \mathrm{~mm}$ size class intervals. All four sample stations were combined. The percentage of different catergories was determined in relation to the total individuals collected each month. To identify the existance of significant difference between the proportions of each sex, we employed a $\chi^{2}$ test, using the sex ratio (female/males) of the complete data set. The relationship between body length (BL) and carapace length (CL) and between the size of the breeding females and the number of embryos or larvae were investigated using regression analysis. To identify the existance of significant difference in environmental parameters and abundance of mysids among staions, we employed Kruskal-Wallis test.

\section{RESULTS}

\section{Environmental variables}

The surface water temperature varied from 25.2 to $35.0^{\circ} \mathrm{C}$ (av. $29.8 \pm 2.35^{\circ} \mathrm{C}$ ) with minimum and maximum respectively during January 1992 and June 1991 (Figure 2). The variation in temperature did not significantly differed among stations (Kruskal-Wallis test: $H=0.34, \mathrm{P}>0.05$ ).

Salinity was generally low during monsoon period (June-September) which progressively increased from post-monsoon period (October -January) attaining maximum during the pre-monsoon period (February-May) (Figure 2). The salinity ranged from 28.8-36.7 with an average of 32.0 \pm 5.4 at V1, 20.5-36.6 with an average of 32.7 \pm 5.0 at V2, 20.1-36.1 with an average of 32.0 \pm 5.2 at V3, 18.1-36.2 with an average of $30.7 \pm 5.6$ at V4. The variation in salinity between stations was not significant $(H=1.75, \mathrm{P}>0.05)$.

\section{Biometrics}

An allometric relationship between the carapace length CL (in $\mathrm{mm}$ ) and the total body length BL (in mm) was calculated from measurements taken in some well-preserved individuals: $\mathrm{BL}=$ $\log 2.158 \log C L+0.883,(r=0.912, n=108, P>0.01)$. 


\section{ABUNDANCE AND POPULATION STUCTURE}

The population densities of Mesopodopsis orientalis in the study area were ranged from 0 2104 ind. $\mathrm{m}^{-3}$, with an average of 78.6 ind. $\mathrm{m}^{-3}$ (Figure 3). The variation in densities significantly differed among stations (Kruskal-Wallis test: $H=8.0, \mathrm{P}<0.05$ ). Maximum population was recorded at station V1 (65.3\%) followed by V2 (22.9\%), V4 (6.9\%) and V3 (4.9\%). There was a clear seasonal variation in the distribution of $M$. orientalis during the present study. Compared with other seasons, the high abundance of $M$. orientalis occurred in the pre-monsoon period (February-May) (83.6\% of the total population with an average of $813.0 \pm 1212$ ind. $^{-3}$ ). During the monsoon (June-September) and Post-monsoon (October-January) period M. orientalis occurred with an average of $130.4 \pm 102.3$ ind. $\mathrm{m}^{-3}$ and 32.2 \pm 22.4 ind. $\mathrm{m}^{-3}$ respectively. Peak in mysid standing stock (av.729.5 \pm 993.2 ind. $^{-3}$ ) was in May 1991 followed by a second peak (av. 172.5 \pm 345.0 ind.m ${ }^{-3}$ ) in April 1992 (Figure 3), in both the peaks, juveniles dominated constituting $93.7 \%$ and $89.6 \%$ of the respective population. In the present study, $M$. orientalis occurred in temperature and salinity range of $25.5^{\circ} \mathrm{C}$ to $34^{\circ} \mathrm{C}$ and 20.3 to 37.1 respectively.

The percentage of different demographic categories showed considerable temporal variation during this sampling period (Figure 4). Juveniles were found in all months and dominant in most of the samples. Highest percentage of juveniles obtained in May 1991 and April 1992 and lowest in July $1992(9.7 \%)$. The size range of juveniles was $1.3 \mathrm{~mm}$ to $4 \mathrm{~mm}$. The minimum and maximum body length value of juveniles was obtained in May 1991 and December 1991 respectively (Figure 5). The maximum percentage of immature females obtained from July 1992 (35.4\%). The smallest body length was found in June 1992 (4.5 mm) and the highest in March and April 1992 (6.6 mm) (Figure 5). Breeding females reached maximum percentage in October 1991 (33.3\%) and a minimum in May 1991 and April 1992 (1\%) (Figure 4). Smallest individual was recorded in July 1992 (5.4 $\mathrm{mm}$ ) the largest in $(8.4 \mathrm{~mm}$ ) January 1992 (Figure 5). Empty females were found in all samples except June, September, October and November 1991. The smallest body length $(6.7 \mathrm{~mm})$ value was found in July 1992 and the highest in December 1991 (8.7 mm) (Figure 5). Immature males reached maximum percentage in October 1991 (33.3\%) and found in all samples except in June, July and September 1991. The smallest body length was found in July 1992 (2.7 mm) and the highest in January 1992 (6.8 mm) (Figure 5). Mature males were found in all samples except September, October and November 1991 with a maximum of 33.3\% recorded in July and minimum of 1\% recorded in May 1991 (Figure 4). Body length varied from $5.3 \mathrm{~mm}$ in July 1991 to $8.5 \mathrm{~mm}$ in December 1991 (Figure 5). The maximum percentage of empty females (20\%) was recorded in June 
1991 and 1992 (Figure 4). The body length of male and female individuals was at maximum during post-monsoon months (Figure 6a,b).

Presence of all categories during whole period and the overlap of different generations, suggests existence of more than one generation per year (Figure 5). The average sex ratio (female/male) calculated for the complete data was 1.4, and ranged from 0.6 (June/92) to 2.3 (April/92) (Figure 7). However, the sex ratio fluctuated along the sampling period, this was not significantly different from 1 (Chi-squared test, $\mathrm{P}>0.05$ ).

\section{Breeding females and broods}

Breeding females present all year round and making up $0.7 \%$ to $33.3 \%$ of the total population with an average of $13.4 \%$. The composition of females with egg/embryo (stage I) varied from $25.0 \%$ to $76.0 \%$ of the total gravid female population with an average of $46.5 \%$; that of female with eye less embryo (stage II) from $0 \%$ to $47.4 \%$ with an average of $27.01 \%$; of that females with eyed embryo (stage III) from $0 \%$ to $33.3 \%$ with an average of $26.4 \%$ (Figure 8 ). The body length of ovigerous female had a general tendency to increase as the stage of the embryo progressed. The Kruskal-Wallis test showed significant size difference between groups $(H=22.33, \mathrm{df}=2, \mathrm{P}<0.05)$. The average value were, stage I females, $7.5 \pm 0.77 \mathrm{~mm}(\mathrm{n}=22)$; stage II females, $7.6 \pm 0.49 \mathrm{~mm}(\mathrm{n}=26)$; and stage III females $7.8 \pm 0.87 \mathrm{~mm}(\mathrm{n}=30)$.

Size variation of eggs/embryos ranged from $0.32-0.45 \mathrm{~mm}$ with an average of $0.39 \pm 0.06$. Brood size (number of embryo present in a brood) ranged from $6-18$. There was no correlation between the egg size and female body length (Figure 9a). The body length of $\mathrm{D}_{2}$ embryo was $0.5-$ $1.0 \mathrm{~mm}$ with an average of $0.57 \pm 0.073$ and $\mathrm{D}_{3}$ was $0.9-1.3 \mathrm{~mm}$ with an average of $0.99 \pm 0.081$. The body size of smallest free-living individual was $1.3 \mathrm{~mm}$. The brood number (BN) was closely correlated with female body length (BL) (Figure 9b), and the following regression equation was obtained,

$$
\mathrm{BN}=3.23 \mathrm{BL}-10.97\left(\mathrm{R}^{2}=0.69, \mathrm{n}=78\right)
$$

\section{DISCUSSION}

The study area in the Versova mangrove ecosystem sustains a moderate potential for mysids. The density variation did not show a fully synchronous pattern between the sampling stations. This probably indicates a heterogeneous distribution of the mysid. Population density of mysids in this 
area (av. 78.6 ind. $\mathrm{m}^{-3}$ ) is comparable with that of mysids collected by the same method of adjust salt pan (Bhayander salt pan) (av.71.0 ind. $\mathrm{m}^{-3}$ ) (Biju \& Panampunnayil 2010). In present study, Mesopodopsis orientalis occurred in wide fluctuating saline conditions (20.3-37.1). This species has also been recorded from highly fluctuating saline conditions (eg. Cochin backwater $(0-34.25)$ and Bhayander salt pan (1.2 - 63.6) (see Biju et al., 2009; Biju and Panampunnayil, 2010). Bhattacharya (1982) studied salinity tolerance in the laboratory and reveal that $M$. orientalis of Indian coastal waters could survive under an extremely wide range of salinity conditions, even though it tends towards a low salinity preference, particularly in the early life stages; this ability ensures its wide distribution from sea water to near fresh water conditions. McLusky and Heard (1971) reported that euryhaline species are well adapted to live in an environment with a wide fluctuation in salinity through their capacity to prevent excessive changes in their internal environment by maintain their blood hyper/ hypo-osmotic to the medium.

As in many other mysid species, $M$. orientalis presented considerable fluctuation in its abundance. Principle factor of seasonal abundance of mysid (Mesopodopsis slebberi) is reproduction, which is controlled primarily by environmental temperature (Moffat and Jones, 1993). In the present study, greatest abundance occurred in May 1991 and April and May1992 (premonsoon period), when juveniles constituted $93.72 \%, 89.56 \%$ and $86.10 \%$ of the total population respectively. Intensity of breeding was at the lowest during August 1991 and July 1992 (monsoon period) when the contribution of juveniles to the total population were only $13.97 \%$ and $9.71 \%$ respectively. $M$. orientalis shows variation in their seasonality in abundance with respect to different population. For example, in Cochin backwater, abundance of this species associated with monsoon period (Biju et al., 2009) while in Hooghly estuary, the periodicity in abundance of M. orientalis weekly correlated with the monsoon season (Sarkar \& Choudhury, 1986). Hanamura et al. (2009) reported that there is no evidence of periodicity in the abundance of $M$. orientalis in the Malaysian sandy beach. These observations suggest that the intensity of breeding varies within different population of the same species. The water temperature significantly affects the periodicity and reproductive biology of mysids (Mauchline, 1980; Wittmann, 1984; Johnston et al., 2001). Hanamura et al. (2009) state that stable water temperature reduces the seasonality of mysids in tropical shallow-waters.

The number of females exceeds the number of males in most of the sampled months, a pattern also reported for $M$. orientalis collected from sandy beach, Malaysia (Hanamura et al., 2009) and other species of mysids (e.g. Neomysis Americana (Pezzack and Corey, 1979); Metamysidopsis 
neritica (Calil and Borzone, 2008). Variation in sex ratio of M. orientalis during sampling period was not significantly different from 1. The same was reported for Metamysidopsis neritica (Calil and Borzone, 2008) and M. elongata atlantica (Gama and Zamboni, 1999).

The population structure of $M$. orientalis at Versova mangrove demonstrates the difference in length composition of population and reproductive conditions of the species. The fully-grown specimens reach a length of $8.7 \mathrm{~mm}$ though sexual maturity is attained at a smaller size of $5.4 \mathrm{~mm}$. This suggests that growth is continuous even after sexual maturity has attained. Some immature females collected in July 1992 were larger than ovigerous females collected in the same month. This reveals that total length alone does not determine maturity.

The number of broods carried by females ranged from 6 to 18. Even though large females carried more young, the number of young carried by females of equal body length also varied. The average body length of breeding females increased with the progress of larval development. A similar size increase in breeding females has been reported in varies species of mysids and has been explained as inter- moult growth causing the stretching of the abdomen (Mauchline, 1973; Fenton, 1994). Hanamura et al. (2009) pointed out that somatic growth of the abdomen is not the factor leading to size increase in breeding female population of $M$. orientalis in the Malaysian sandy beach. Unfortunately, in the present study, the somatic growth of abdomen is not measured.

Since in M. orientalis breeding goes on all the year round many broods must be produced by a single female as instanced by the presence of two to three size classes of juveniles in most of the collections, but how long a single individual lives is not known. Calil and Borzone (2008) point out that many species of mysids in shallow water environments have several generations within the year and individual females within a generation may produce several successive broods. An increase in the reproductive potential of a population is related to an accelerated ontogenic development that results in a fast maturation of the individuals, allowing the production of many generations per year. This can hardly be distinguished in field data. However, the study of length-frequency histograms of mature mysids often aid in the interpretation of population biology (Mauchline, 1980). In the present study, the life history of $M$. oroentalis interpreted as follows; the first generation started in April and May with a large cohort. These juveniles become immature males and females observed in June and July, which developed to mature males and ovigerous females in August and September. These ovigerous females originated a new generation in October/November. The generation of October/November becomes immature males and females in December and January and mature individuals in February and March that developed new generation and closing the annual biological 
cycle of M. orientalis (Figure 5). Nair (1939) has described in detail the formation and extrusion of eggs in M. orientalis. The incubating period is not more than 96 hours at $25-29^{\circ} \mathrm{C}$ and the female then moults and immediately lays again.

Field observations on the different population of $M$. orientalis appear to be inconsistent in certain reproductive characters (Table 1). For instance, the maximum size of the ovigerous females of the estuarine population was $7.4 \mathrm{~mm}$, while populations in sandy beach, salt pan and mangrove habitat, those was $8.3 \mathrm{~mm}, 8.1 \mathrm{~mm}$ and $8.4 \mathrm{~mm}$ respectively. Clutch sizes of $M$. orientalis collected from different localities also have some variations. At present, highest number (29) of broods of $M$. orientalis recorded at Hazira, India (Biju \& Panampunnyil, 2009), while the lowest number (6) was at Sandy beach, Malaysia (Hanamura et al., 2009; Table 1) and Versova mangrove, India (present study) (Table 1). Biju and Panampunnayil (2009) reported that M. orientalis collected from different populations of Maharastra and South Gujarat, India showed wide variation in the clutch size. The average egg diameter of sandy beach population was $0.37 \mathrm{~mm}$ (Hanamura et al., 2009) while those of mangrove population were $0.39 \mathrm{~mm}$. Some other species of mysids also shows difference in reproductive characters with respect to habitat, Ishikawa and Oshima (1951) reported that the egg /embryo carried by Neomysis japonica Nakazawa, 1910 was smaller in the population collected in a low salinity environment than that in that collected in a high salinity area. However, Sawamoto (1985) obtained an opposite result for the same species in neighboring water of Japan. Delgado et al. (1997) mentioned that clutch size of Mesopodopsis slabberi (van Beneden) vary depending on the geographic populations or different generations. Even though many factors affecting the mysid reproduction, different pattern of reproductive traits may be related with their genetic variability. Hanamura et al. (2008b) reported that the difference in life history trait of mysids linked with their genetic background and recent taxonomic analysis with molecular data has revealed high genetic diversification and /or cryptic speciation in several cosmopolitan species of mysids (Audzijonyte \& Väinölä, 2005, Remerie et al., 2006, Hanamura et al., 2008b). From this viewpoint, more morphometric and genetic analyses are needed to clarify the difference in life history features within different population of the same species.

\section{ACKNOWLEDGEMENTS}

The authors are grateful to the Director, National Institute of Oceanography, Goa and to the Scientist-in-Charge, Regional Centre, NIO, Kochi for the encouragement and facilities provided. Thanks are due to the Scientist-in-Charge, NIO, Mumbai for providing the study material. This is NIO contribution. 


\section{References}

Audzijonyte A. and Väinölä R. (2005) Diversity and distributions of circumpolar fresh- and brackish-water Mysis (Crustacea: Mysida): descriptions of M. relicta Lovén, 1862, $M$. salemaai n.sp., M. segerstralei n.sp. and M. diluviana n.sp., based on molecular and morphological characters. Hydrobiologia 544, 88 - 141.

Baldo F. and Drake P. (2005) A multivariate approach to the feeding habits of small fishes in the Guadalquivir Estuary. Journal of Fish Biology 61, 21 - 32.

Bhattacharya S.S. (1982) Salinity and temperature tolerance of juvenile Mesopodopsisorientalis: laboratory studies. Hydrobiologia 93, $23-30$.

Biju A. and Panampunnayil S.U. (2009) Mysids from the shallow waters off Maharashtra and south Gujarat, India, with description of a new species. Marine Biology Research 5, 345 362 .

Biju A. and Panampunnayil S.U. (2010) Mysids (Crustacea) from the salt pans of Mumbai, India, with a description of a new species. Marine Biology Research 6, 556 - 569.

Biju A., Gireesh R., Jayalakshmi K.J., Haridevi C.K. and Panampunnayil S.U. (2009) Seasonal abundance, ecology, reproductive biology and biochemical composition of Mesopodopsis orientalis W.M. Tattersall (Mysida) from a tropical estuary, Cochin backwater-India. Crustaceana 82: 981 - 996.

Calil P. and Borzone P.C. (2008) Population structure and reproductive biology of Metamysidopsis neritica (Crustacea:Mysidacea) in a sandy beach in south Brazil. Revista Brasileira de Zoologia 25 (3), $403-412$.

Chaitiamwonges S. and Yoodee K. (1982) Fisheries of planktonic shrimp and shrimp-like in the Gulf of Thailand. Thai Fish Gazet 35, 67 - 88.

Delgado L., Guerao G. and Ribera C. (1997) Biology of the mysid Mesopodopsis slabberi (van Beneden, 1861) (Crustacea, Mysidacea) in the coastal lagoon of the Ebro delta (NW Mediterranean). Hydrobilogia 357, 27 - 35.

Fenton G.E. (1994) Breeding biology of Tenagomysis Tasmania Fenton, Anisomysis mixta australis (Zimmer) and Paramesopodopsis rufa Fenton from south-eastern Tasmania (Crustacea: Mysidacea). Hydrobiologia 287, 259 - 276.

Gama A.M.S., Zamboni A.J. (1999) Aspectos da biologia e do cultivo de Metamysidopsis elogata atlantica para uso em testes de toxicidade. Nauplius 7, $127-139$.

Hanamura Y., Siow R. and Chee P-E. (2008a) Reproductive biology and seasonality of the IndoAustralasian mysid Mesopodopsis orientalis (Crustacea: Mysida) in a tropical mangrove estuary, Malaysia. Estuarine, Coastal and Shelf Science 77,

$467-474$.

Hanamura Y., Koizumi N., Sawamoto S., Siow R. and Chee P-E. (2008b) Reassessment of the taxonomy of Mesopodopsis orientalis (Tattersall, 1908) (Crustacea, Mysida) and proposal of a new species for the genus with an appendix on M. zeylanica Nouvel, 1954. Journal of Natural History 42, $2461-2500$. 
Hanamura Y., Siow R., Chee P-E. and Kassim. (2009) Seasonality and biological characteristic of the shallow water mysid Mesopodopsis orientalis (Crustacea: Mysida) on a tropical sandy beach, Malasia. Plankton Benthos Research 4, 53 - 61.

Ishikawa M. and Oshima Y. (1951) On the life history of a mysid crustacean, Neomysis japonica Nakazawa. Bulletin of the Japanese Society of Scientific Fisheries 16, 461 - 472.

Johnston W.S., Stevens M. and Watling L. (2001) Reproduction and development of marine peracaridans. Advances in Marine Biology 39, 105 - 260.

Jumars P.A. (2007) Habitate Coupling by mid latitude, subtidal, marine mysids: Import-subsidised omnivores. Oceanography and Marine Biology 45, 89 - 138.

Mauchline J. (1973) Inter moult growth of species of Mysidacea (Crustacea). Journal of the Marine Biological Association of the United Kingdom 53,801 - 817.

Mauchline J. (1980) The biology of Mysids. Advances in Marine Biology 18: 1-369.'

McLusky D.S. and Heard V.E. (1971) Some effect of salinity on the mysid Praunus flexous. Journal of Marine Biological Association of United Kingdom 51, 709 -715.

Moffat A.M. and Jones M.B. (1993) Correlation of the distribution of Mesopodopsis slabberi (Crustacea, Mysidacea) with physico- chemical gradients in partially mixed estuary (Tamar, England). Netherlands Journal of Aquatic Ecology 27: 155 - 162.

Nair K.B. (1939) The reproduction, oogenesis and development of Mesopodopsis orientalis Tattersall. Proceedings of the Indian Academy of Sciences 9, 175 - 223.

Patil S.W. and Sankolli K.N. (1991) Kolim (Mysid) Fishery of North Konken Coast. Fishery Technology (special issue) Low Energy Fishing- Proceedings of the National Workshop on Low Energy Fishing, held at Cochin.

Pezzack D.S. and Corey S. (1979) The life history and distribution of Neomysis Americana (Smith) (Crustacea, Mysidacea) in Passamaquoddy Bay. Canadian Journal of Zoology 57, 785 - 793.

Pinkaew K., Ohtsuka S., Putchakara S., Chalermwat K., Hanamura Y. and Fukuoka K. (2001) Preliminary survey of mysid fauna in the Gulf of Thailand. Proceedings of the $11^{\text {th }}$ JSPS Joint Seminar on Marine Science, University of Tokyo, pp. 256 -273.

Remerie T., Bourgois T., Peelaers D., Vierstraete A., Vanfleteren J. and Vanreusel A. (2006) Phylogeographic patterns of the mysid Mesopodopsis slabberi (Crustacea, Mysida) in Western Europe: evidence for high molecular diversity and cryptic speciation. Marine Biology 149, 465 - 481 .

Sarkar S.K. and Chowdhury A. (1986) On the occurrence and abundance of Mesopodopsis orientalis (W.M.Tattersall) (Crustacea-Mysidacea) from Hoogly estuary. Mahasagar 19, 203 $-207$.

Sawamoto S. (1985) Some observations on population composition and life history of Neomysis japonica (Mysidacea. Crustacea) in Shima Peninsula. Central Japan. Bulletin of the Institute of Oceanic Research and Development, Tokai University 7, 33 - 39. 
Stephen R., Jayalaksmi K.V. and Nair V.R. (2003) Intermittent swarming of copepods in versova mangrove, Mumbai. Seshatyana 2(1), 5 - 7.

Takahashi K., Hirose T. and Kawaguchi K. (1999) The importance of Intertidal sand -burrowing peracarid crustaceans as prey for fish in the surf-zone of a sandy beach in Otsuchi Bay, Northern Japan. Fisheries Science 65, 856 - 864.

Tattersall W.M. (1915) Mysidacea. Fauna of the Chilka Lake. Memories of Indian Museum 5, 149 161.

Vijay V., Biradar R.S., Inamdar A.B., Deshmukhe G., Baji S. and Pikle M. (2005) Mangrove mapping and change detection around Mumbai (Bombai) using remotely sensed data. Indian Journal of Marine Science 34(3), 310 - 315.

Wittmann K.J. (1984) Ecophysiology of marsupial development and reproduction in Mysidacea (Crustacea). Oceanography and Marine Biology: Annual Review 22, 393 - 428.

Yamada K., Takahashi K., Vallet C., Taguchi S. and Toda T. (2007) Distribution, life history, and production of three species of Neomysis in Akkeshi-ko estuary, northern Japan. Marine Biology 150, $905-917$. 


\section{Figure captions}

Figure 1. Map showing the study area and sampling locations in the Versova mangrove system, India.

Figure 2. Temporal variations in the water temperature and salinity observed at the sampling sites in the Versova mangrove system, India.

Figure 3. Abundance of Mesopodopsis orientalis averaged four stations from May 1991 to July 1992 in Versova mangrove system, India.

Figure 4. Seasonal changes in population structure of Mesopodopsis orientalis collected in the Versova mangrove system, India. MM, matured male; IM, immature male; EF, empty female; BF, breeding female; IF, immature female; J, juveniles.

Figure 5. Mesopodopsis orientalis. Length-frequency histograms from May 1991 to July 1992 in Versova mangrove. (histograme for October 1991 were not in included due to low occurense of mysids on these sampling). $n$ indicates number of individuals collected.

Figure 6. Mesopodopsis orientalis. Seasonal variation of the mean body length of immature and mature males (a) and immature and mature females (b).

Figure 7. Monthly variation in sex ratio (female/male) of Mesopodopsis orientalis in the Versova mangrove.

Figure 8. Sesonal changes in the percentage occurrence of brooding females of Mesopodopsis orientalis in the Versova mangrove.

Figure 9. Mesopodopsis orientalis. Relationship between egg diameters and body length (n=35) (a) and between brood number per female and body length $(n=78)(b)$. 
Table 1. Comparison in reproductive character of Mesopodopsis orientalis with different population

\begin{tabular}{|c|c|c|c|c|c|c|c|}
\hline $\begin{array}{l}\text { Different } \\
\text { populations }\end{array}$ & $\begin{array}{l}\text { Geographical } \\
\text { area }\end{array}$ & $\begin{array}{l}\text { Largest } \\
\text { male } \\
(\mathrm{mm})\end{array}$ & $\begin{array}{l}\text { Largest } \\
\text { female } \\
(\mathrm{mm})\end{array}$ & $\begin{array}{l}\text { Size of } \\
\text { ovigerou } \\
\text { s female } \\
(\mathrm{mm})\end{array}$ & $\begin{array}{l}\text { Egg size } \\
(\mathrm{mm})\end{array}$ & $\begin{array}{l}\text { Clutch } \\
\text { size } \\
(\mathrm{mm})\end{array}$ & References \\
\hline Estuary & $\begin{array}{l}9^{\circ} 40^{\prime} 12^{\prime \prime} \mathrm{N}- \\
76^{\circ} 23^{\prime} 57^{\prime \prime}\end{array}$ & 7.6 & 8.3 & $4.7-7.4$ & $0.39-0.47$ & $8-12$ & $\begin{array}{l}\text { Biju et al., } \\
2009\end{array}$ \\
\hline Sandy beach & $\begin{array}{l}5^{\circ} 17^{\prime} 09^{\prime \prime} \mathrm{N}- \\
100^{\circ} 14^{\prime} 02^{\prime \prime} \mathrm{E}\end{array}$ & 7.1 & 8.3 & $5.2-8.3$ & $0.30-0.42$ & $6-24$ & $\begin{array}{l}\text { Hanamura } \\
\text { et al., } 2009\end{array}$ \\
\hline Salt pan & $\begin{array}{l}19^{\circ} 03^{\prime} 42^{\prime \prime} \mathrm{N}- \\
72^{\circ} 48^{\prime} 45^{\prime \prime} \mathrm{E}\end{array}$ & 8.6 & 9.8 & $6.0-8.1$ & - & $10-18$ & $\begin{array}{l}\text { Biju \& } \\
\text { Panampunn } \\
\text { ayil, } 2010\end{array}$ \\
\hline Mangrove & $\begin{array}{l}19^{\circ} 07^{\prime} 30^{\prime \prime} \mathrm{N}- \\
72^{\circ} 49^{\prime} 30^{\prime \prime} \mathrm{E}\end{array}$ & 8.5 & 8.7 & $5.4-8.4$ & $0.32-0.45$ & $6-18$ & $\begin{array}{l}\text { Present } \\
\text { study }\end{array}$ \\
\hline
\end{tabular}


Figure 1

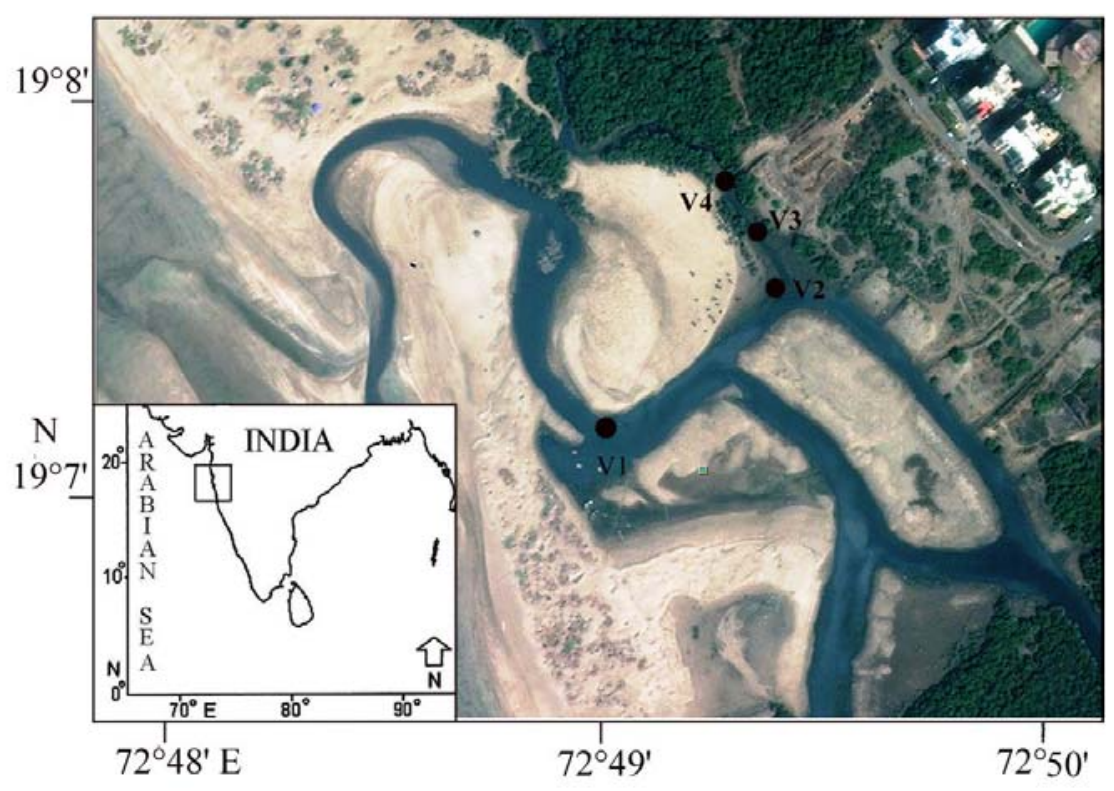


Figure 2

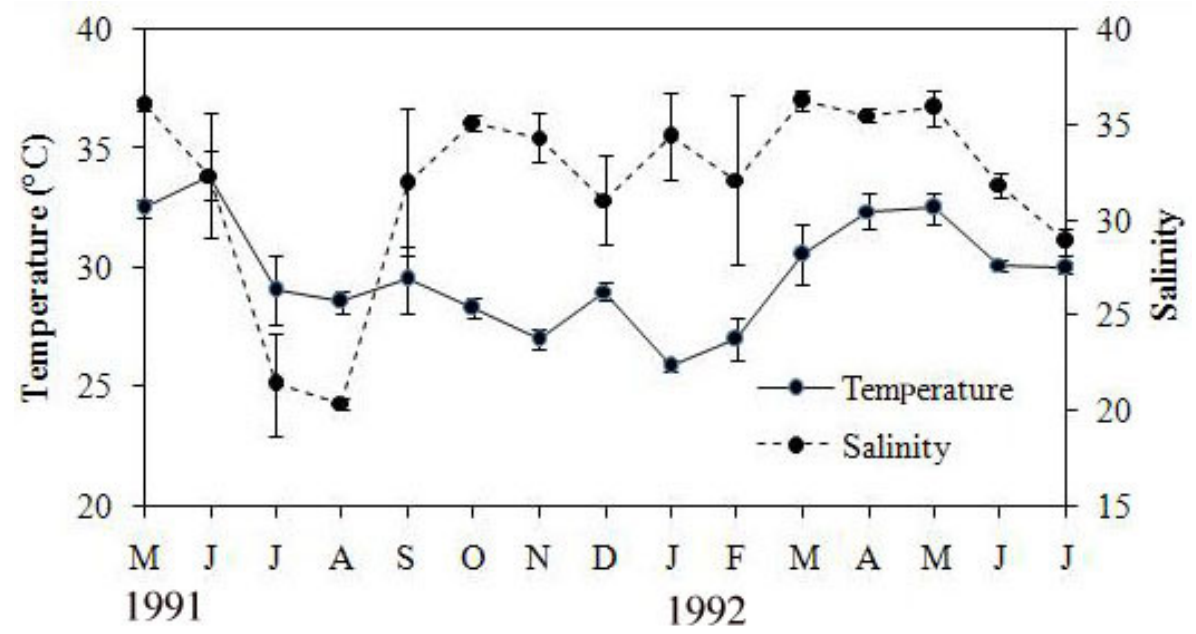


Figure 3

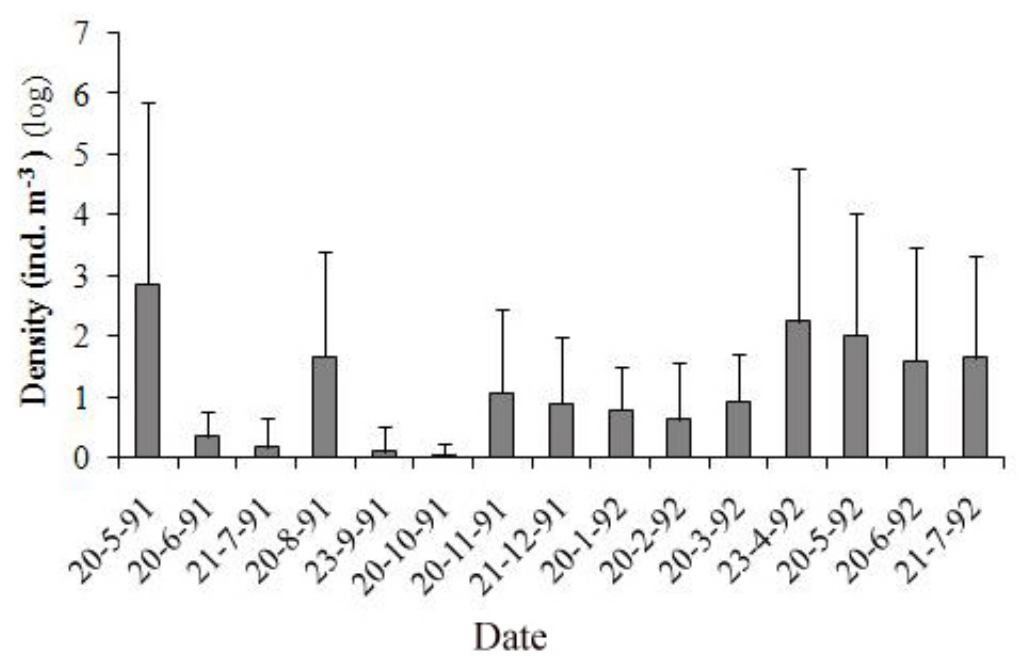


Figure 4

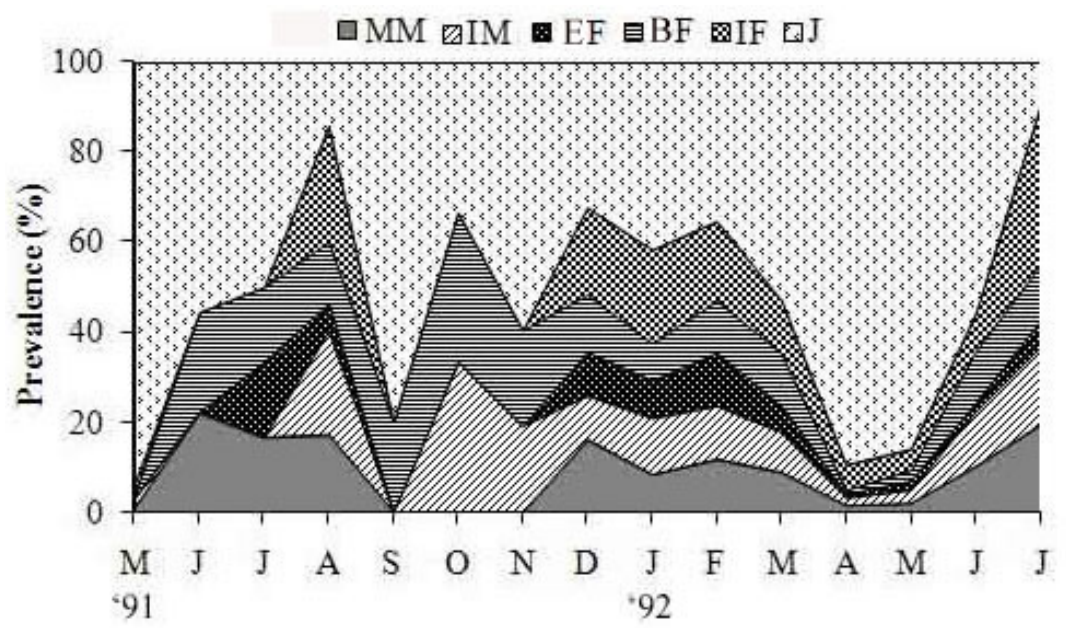


Figure 5

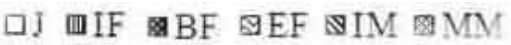
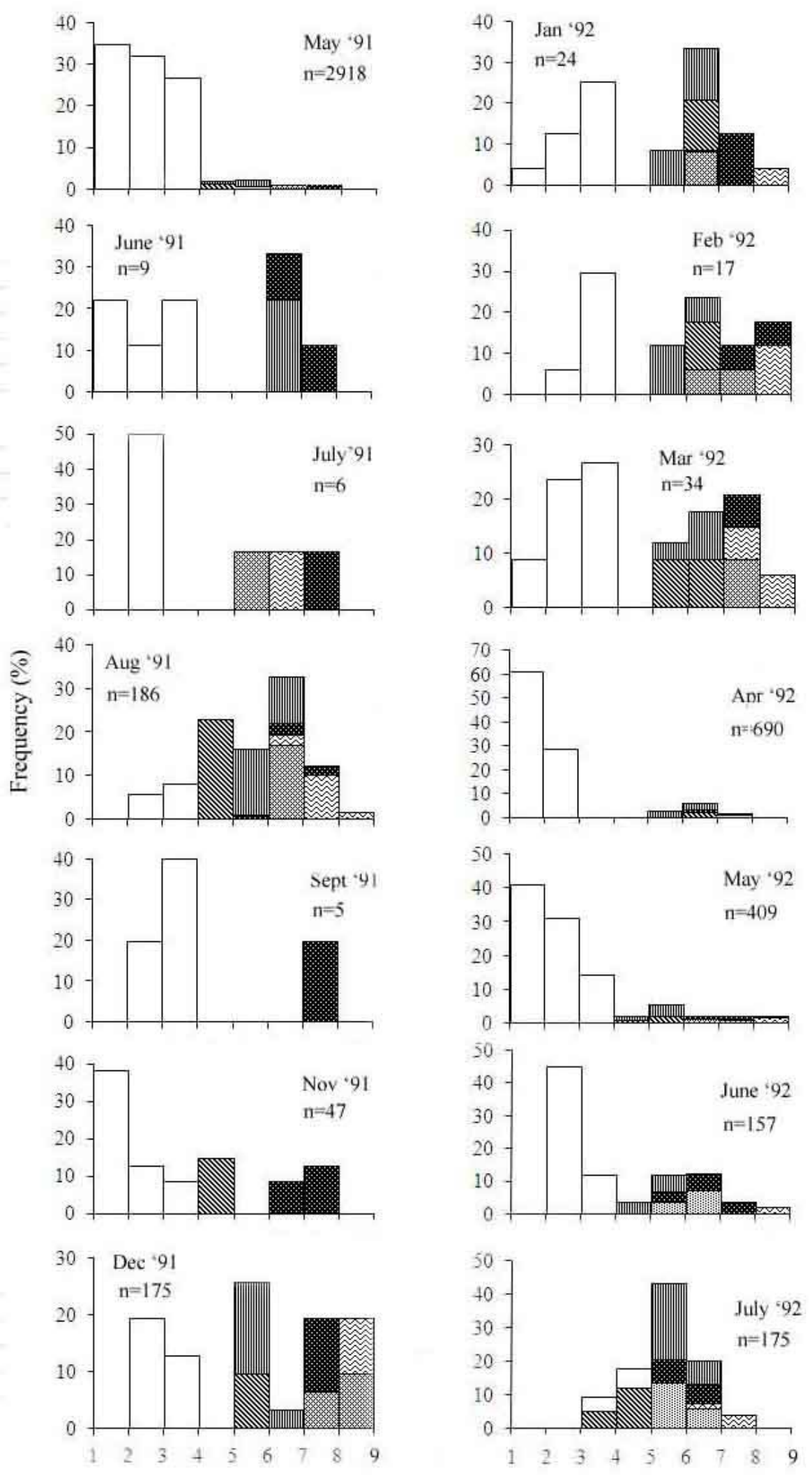

Length (mm) 
Figure 6

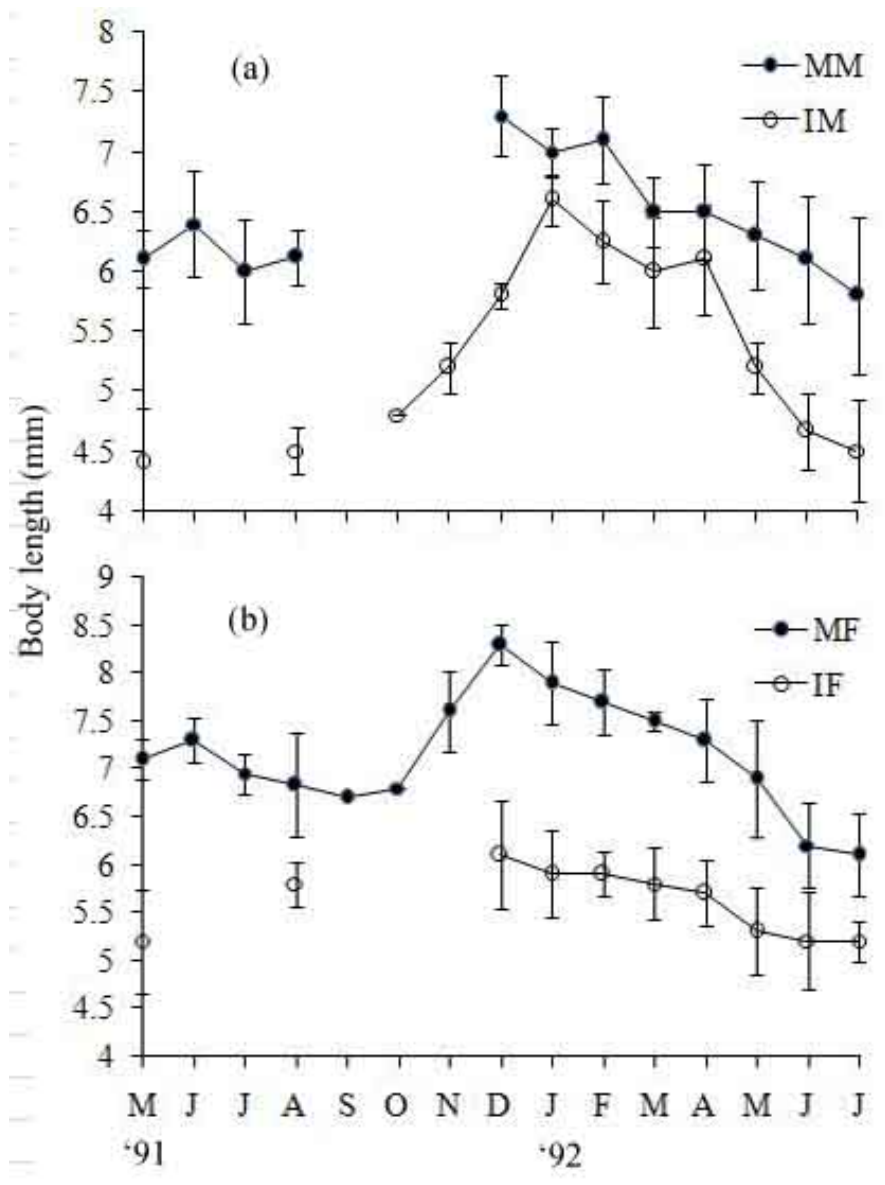


Figure 7

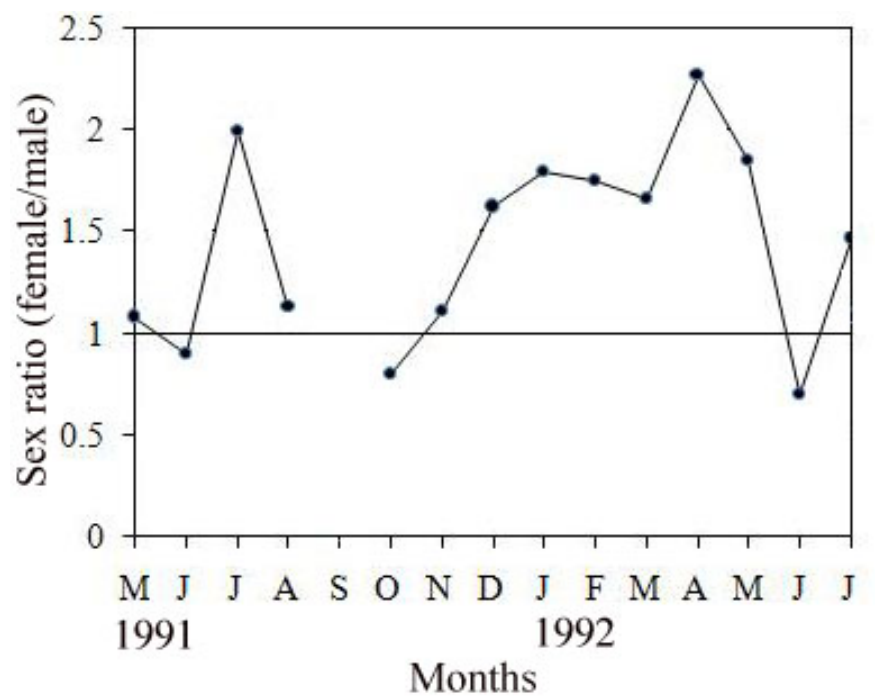

Figure 8

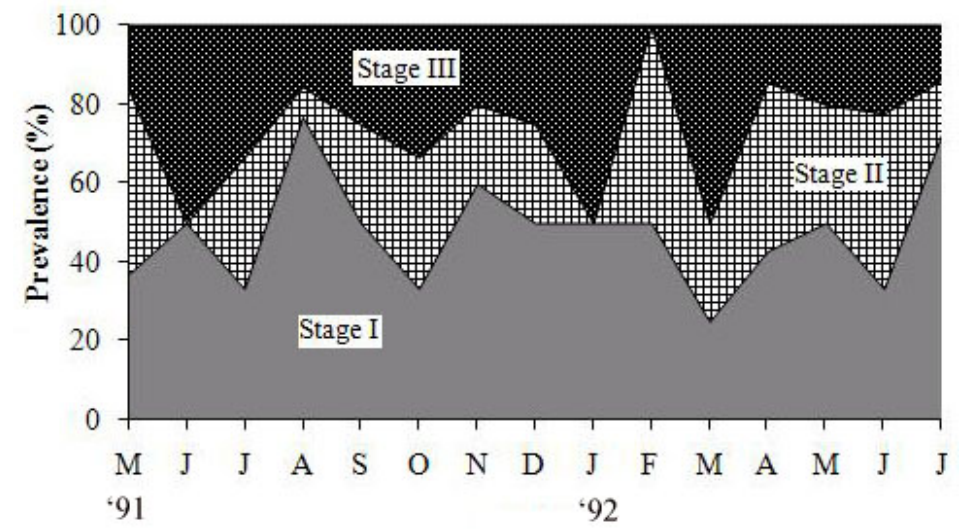


Figure 9
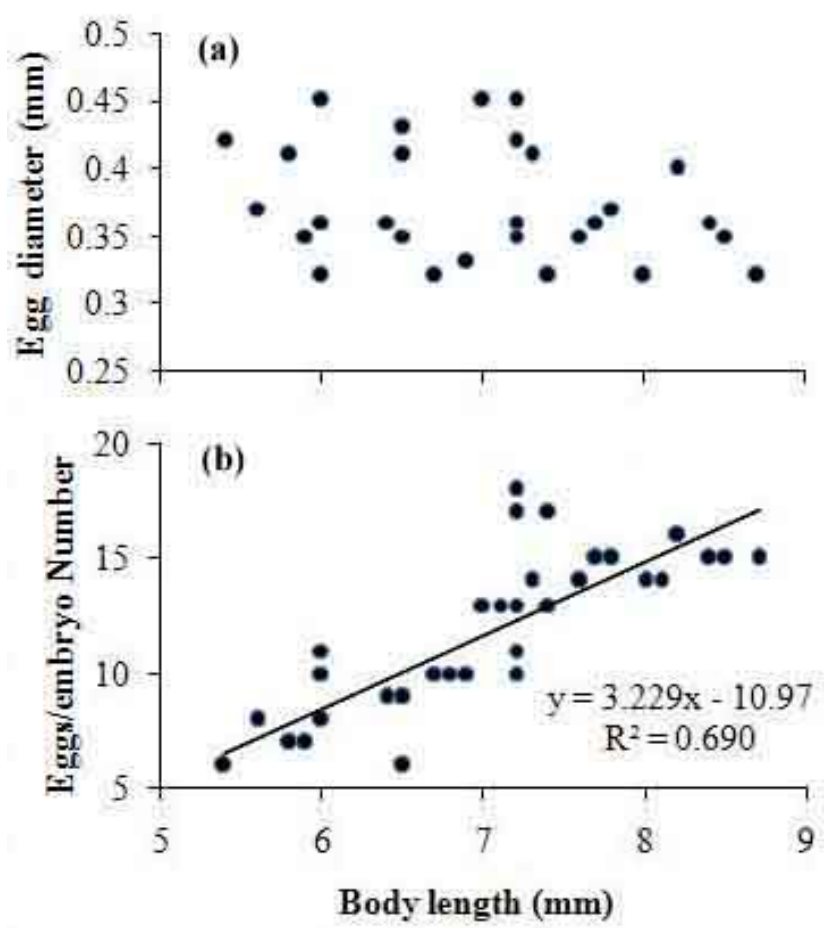